\title{
The 'Verdict Paradox' and the Liar Paradox: How Logic Can Defend the Rule of Law. A Study of the Polish Constitutional Crisis ${ }^{1}$
}

\author{
Szymon Mazurkiewicz \\ Jagiellonian University, Cracow, Poland \\ szymon.mazurkiewicz@uj.edu.pl
}

Received 23 July 2018; accepted 23 Jauary 2019; published 30 June 2019.

\begin{abstract}
This paper aims to present how logic may undermine a parliamentary assault on democratic institutions (representing legal guarantees of the rule of law and political freedom) based on the analysis conducted with reference to the so-called Polish constitutional crisis. I analyse whether a law can be reviewed on the basis of this law itself. The Polish Constitutional Tribunal faced such a problem while passing the verdict of $9^{\text {th }}$ March, 2016, regarding the constitutionality of the amendment to the Statute on the Constitutional Tribunal from $22^{\text {nd }}$ December, 2015. This problem, called a 'verdict paradox', was claimed to be a type of the Liar paradox. I argue that, contrary to the common view, the problem of the verdict paradox is not based on the Liar paradox; for this purpose, a logical analysis is applied to four variants of a reasoning with regard to the constitutionality of the said amendment. The distinction between two levels of analysis concerning emerging reasonings, namely an abstract (logical) level and a concrete level placed in the context of the legal system, is also introduced. This paper demonstrates that although only two variants of the reasoning concerning a law's judicial review based on the law itself involve logical contradiction, the possibility of employing reasonings from other variants must be excluded, albeit due to alternative reasons. Therefore, the Constitutional Tribunal's decision to avoid the verdict paradox by passing over the reviewed provisions in the review process was correct and might be perceived as an example of how logic and reason can defend the institutional guarantees of political freedom.
\end{abstract}

\footnotetext{
${ }^{1}$ The paper was written as a result of realization of the research project number 2017/27/N/HS5/00856 financed by National Science Centre, Poland.
} 
Keywords: Polish constitutional crisis; Constitutional Tribunal verdict of $9^{\text {th }}$ March 2016; amendment to the Statute on the Constitutional Tribunal from 22 ${ }^{\text {nd }}$ December 2015; verdict paradox; Liar paradox; logical contradiction; constitutional contradiction; political freedom guarantees.

\section{Introduction ${ }^{2}$}

The rule of law is by far one of the most important features of the liberal democracy and a safeguard against infringements of political liberties, as it constitutes its foundations. When liberal values are widely accepted and unthreatened by both state authorities and extremist, anti-liberal movements, social and commonly shared acceptance suffices as a guarantee of political freedom. Nevertheless, when a political situation changes and either the state authorities become too powerful or the majority of society ceases to believe in liberal values, the rule of law and political freedom can be easily violated or even destroyed. For that reason, in order to prevent possible infringements of political freedom, some institutional precautions are introduced, one of which is the constitutional court possessing the competence to review parliamentary enactments and determine the unconstitutionality of law. However, what can be done when the constitutional court is under some sort of legal assault involving a parliamentary enactment leading to the constitutional court's deprivation of its constitutional entitlements? Is only a political authority capable of rescuing the constitutional court and restoring its constitutional competences? In this paper, I will examine these questions based on the Polish constitutional crisis while focusing on the verdict of the Polish Constitutional Court from $9^{\text {th }}$ March, 2016 (K 47/15).

\section{The Polish Constitutional Crisis}

In 2015, the so-called Polish constitutional crisis arose. ${ }^{3}$ Briefly, from a legal point of view, prior to the forthcoming parliamentary election, the governing majority of the Civic Platform (Platforma Obywatelska, abbrev. PO) had elected five new judges to the Constitutional Tribunal (CT). The constitutionality of this election was challenged and the CT was set to review the amendment to the Statute on the CT that had allowed that election. These judges were not officially appointed as the CT judges. The next parliamentary election was won by the Law and Justice (Prawo i Sprawiedliwość, abbrev. PiS) and they formed a new

\footnotetext{
${ }^{2}$ I would like to thank Tomasz Gizbert-Studnicki for useful discussions and critical comments

${ }^{3}$ My short description of the first phase of the Polish constitutional crisis consists merely of the crisis' legal aspects. Political aspects are much more important for the thorough understanding of all aspects, although it is not the aim of this paper to discuss the crisis' political origins and/or motivations of the Law and Justice politics against the CT. For a legitimate study covering these points, see Matczak (2018). For an analysis based mainly on the constitutional law, see Radziewicz (2017), Stębelski (2017), and Młynarska-Sobaczewska (2017). In order to get familiarised with some political and legal arguments supporting the constitutionality of the Law and Justice changes in the CT, see Morawski (2017) and Czarnota (2017), whilst for a German voice see Dziadzio (2018).
} 
government. PiS maintained that the election of those five judges had been illegal and the parliament adopted the resolution favouring the invalidity of that election, which was a precedence unknown to the Polish legal system. Therefore, the Law and Justice elected their own five new judges to the CT. That same day, these judges were officially appointed as the CT judges. However, the President of the Constitutional Tribunal Justice did not allow three of the five judges elected by PiS to perform their judicial duties due to the unconstitutionality of their appointment. Meanwhile, the CT issued the verdict, stating that PO's election of two out of five judges had been unconstitutional and making that selection null and void. As a consequence, three judges appointed by PiS were appointed illegally, because they were elected during a time when no vacant positions were available. The amendment allowing the appointment of these judges was also challenged to the CT.

Moreover, the governing majority enacted an amendment from $22^{\text {nd }}$ December, 2015, to the Statute on the CT (henceforth referred to as 'the amendment', whilst I shall refer to the previous version of the Statue on the CT as 'Statue on the CT'), which altered many crucial procedural rules as, among others, it introduced the obligation to pass verdicts by the majority of $2 / 3$ rather than the simple majority, as well as the obligation that verdicts be passed on the panel of thirteen judges. These provisions were widely perceived as obviously unconstitutional, as the Constitution, in art. 190(5), literally states that the verdicts are passed just by the majority. The amendment was challenged by five different motions and CT was set to review it. The political goal of these changes was to place Andrzej Rzepliński, the President of the Constitutional Tribunal Justice, in a predicament. On the one hand, had Rzepliński allowed those three judges to perform their judicial duties, he would have accepted the legality of their appointment; on the other hand, had he done otherwise, the governing majority would have claimed that he violated the valid law. ${ }^{4}$ In the first scenario, PiS would have won in a legal manner with five judges, thus blocking power, as the verdict must have been issued by a $2 / 3$ majority. In the second scenario, another argument against the role of the CT would have been obtained, as one of PiS's main political arguments was that the judiciary in general-and the CT in particularusurps much more competence than it should possess in democracy, since the President of the CT cannot independently decide who actually is the judge of the CT against the valid statute. As a result, another point would have been given during the process of politically delegitimising the $\mathrm{CT}$ and the judiciary as a whole.

\footnotetext{
${ }^{4}$ Note that, under the Polish legal system, only the CT possesses the competence to examine the general constitutionality of the law. It used to be widely held by the legal doctrine that common courts and the Supreme Court could not review parliamentary enactment, although the Constitution states in art. 8(2) that the Constitution is applied directly. Generally, such a doctrine distinguishes the continental form of judicial review from the U.S. form. On the other hand, as a result of the CT being deprived of its independent position during the crisis, it has been held since 2016 that a common court is able to not apply some statutory regulations toward a specific case wherein a court claims that this statute is unconstitutional. Still, only the CT possesses the competence to pass a verdict regarding the universal unconstitutionality of a legal regulation and, thus, generally exclude it from the scope of legal norms.
} 


\section{The 'Verdict Paradox'}

While Andrzej Rzepliński was faced with a no-win political situation, the whole CT had been confronted with what was later described as the 'verdict paradox'. The amendment that was to be reviewed consisted of no vacatio legis. One of the challenged articles regarded the obligation of passing a verdict by a $2 / 3$ majority within the panel of thirteen judges. Due to no vacatio legis, the challenged provisions happened to be both the subject of review and the procedural and institutional basis of the review process. That situation was labelled as the 'verdict paradox'. Legal rules were to be reviewed on their own basis, which seemed absurd. Moreover, another point raised in the political dispute was that if President Rzepliński had allowed three judges to participate in passing the verdict and the verdict had been that the amendment was unconstitutional, ${ }^{5} \mathrm{PiS}$ might have claimed that the legal basis of the verdict became invalid, and, as a consequence, the verdict was invalid as well. If the CT had managed to implement some doctrinal tool and omit the challenged regulations in the review process, the governing party would have claimed that the CT did not obey the valid law and, thus, the verdict would have also been considered invalid. ${ }^{6}$

The CT decided to pass over the challenged provisions of the amendment that were to be reviewed, instead examining the constitutionality of the amendment on the basis of the Constitution itself, the unchallenged provisions of the amendment, and, subsidiary, the previous version of the Statue on the CT in lieu of the passed-over provisions. The CT claimed that a regulation could not simultaneously be both the subject of review and the basis of review. Such a decision has been widely accepted in the legal doctrine and has been considered an effective way to avoid the underlying paradox. ${ }^{7}$ Some claimed that the verdict paradox was a variation of the old logical and philosophical Liar paradox (Pach \& Dyrda, 2016a, 2016b; Pietrzykowski, 2016). If that had been the case, then an extremely strong, logical background for the correctness of the CT's decision would have been provided.

However, I will claim that the verdict paradox is not a variant of the Liar paradox and that the emerging contradiction is not fully logical. There are other reasons - although they may be of extendedly logical nature - to claim that the decision of the CT to pass over the challenged regulations was correct, and I intend to present these. I will rely on two levels of analysis, including logical (abstract) and legal (practical) level. The logical level allows some states of affairs to obtain that are otherwise impossible to obtain on the legal level.

\footnotetext{
${ }^{5}$ This was, however, hardly imaginable, as there would have been additional pro-PiS judges who could block any decision regarding the unconstitutionality of the amendment.

${ }^{6}$ What actually happened was that the CT followed this path and the Polish Prime Minister refused to officially publish the verdict in the Journal of Laws, which was the formal condition of the universal validity of a verdict of the CT. The Polish Constitution clearly does not provide the Prime Minister with the competence to review CT verdicts.

${ }^{7}$ Matczak (2017) also proposes another kind of resolution not only for this paradox, but also for constitutional crises themselves by applying Barber's (2013) conception of institutional self-defence.
} 
In other words, logical analysis makes it possible to reveal certain subtleties of the discussed issue, which are impossible to be grasped at the practical (legal) level of analysis. Such a mode of analysis is based on a modalities framework wherein many modalities irreducible to one another occur (Fine, 2002; Rumberg, 2016). The deeper the level of modality is, the fewer situations are considered impossible. For instance, it is technically impossible to travel from London to New York in fifteen minutes, while it is indeed possible on the physical level; it would be only physically impossible to travel faster than the speed of light. On the other hand, under a lower level of modality, all deeper modalities must be preserved; if it is logically impossible to be simultaneously in place A and place not-A, it is impossible in our world to simultaneously be in both London and New York, assuming that these are two different places (Fine, 2002; Rumberg, 2016). For this study, therefore, I distinguish the logical level from the legal level; the logical level involves abstract, logical issues, whereas the legal level can add its new modalities related to the nature of legal institutions and legal reasoning. Significantly, the legal level must preserve all modalities from the logical level.

\section{The Liar Paradox}

The Liar paradox, formulated 2,500 years ago, occurs while trying to ascribe true/false values to the sentence: 'This sentence is false'. Firstly, assume this sentence is true; because the sentence 'this sentence is false' is true, it is actually false, as its wording suggests. Secondly, assume this sentence is false; if the sentence 'this sentence is false' is false, it is true that the negation of a sentence has a contrary true/false value. Each time a contrary value is obtained other than the one that is initially assumed, which is why a paradox occurs.

It has been argued that the verdict paradox is a variation of the Liar paradox in a normative or legal domain (Pach \& Dyrda, 2016a, 2016b; Pietrzykowski, 2016). ${ }^{8}$ If the CT had issued the verdict on the constitutionality of the amendment's provisions on the basis of the amendment's provisions and judged that they were unconstitutional, then the amendment's provisions would have been unconstitutional. The basis of judicial review would have been constituted from the rules, which had been deemed unconstitutional. This would reduce the whole review to the statement: 'on the basis of the constitutional provisions of the amendment, Constitutional Tribunal decides that the provisions of the amendment are unconstitutional'. Such a statement is absurd and might have become a ground for the thesis advocated by PiS, namely that the verdict was illegal and invalid, ${ }^{9}$ as in that moment it stated the unconstitutionality of its subject it stated simultaneously unconstitutionality of its own basis. According to the proponents of the notion that the verdict paradox is a sort of the Liar paradox, what justified this paradox as being a variant of the Liar paradox

\footnotetext{
${ }^{8}$ J. Woleński (2018) also considers the possibility of applying Godel's incompleteness theorem and Kelsen's analysis of the validity of law, particularly of the validity of the basic norm. However, Woleński eventually chooses to reject all of them.

${ }^{9}$ This is in spite of the fact that the Polish Constitution does not provide such a category for CT verdicts.
} 
is that, on the basis of the constitutional provisions of the statute, it may be argued that provisions of the statute are unconstitutional. The true/false value must be altered into a valid/invalid or a constitutional/unconstitutional value, and the change from validity to invalidity or constitutionality to unconstitutionality occurs just as the change from truth to falsity in the Liar paradox occurs. This claim is based on the assumption that, in the legal domain, valid/invalid values correspond with — and play the role of - general true/false values (Woleński, 2012, pp. 143-158). The rule 'if one commits a tort, they need to compensate the loss' has the value of validity, just as the statement 'grass is green' has the value of truth. Validity is the relation of a legal rule to a legal system, just as truth is the relation of a statement to the world. Due to the fact that every legal rule must be in accordance with the constitution of the state, constitutional legal rules are, generally, valid legal rules, while unconstitutional legal rules are, generally, invalid legal rules. ${ }^{10}$ Thus, I believe that every constitutional legal rule is, by nature, also a valid legal rule. In the next parts of this paper I will use formulations of constitutional/unconstitutional values in reference to the verdict paradox.

Some clarification concerning the nature of a judicial review must be provided. A judicial review can be declaratory or constitutive; under a declaratory judicial review, a competent body (e.g. the CT in Poland) declares an objective state of affairs, namely that a law is unconstitutional. Legislation is unconstitutional and thus invalid from the very beginning, and only a binding declaration of such a status must be provided. In turn, under the constitutive judicial review, a competent body invalidates a statute or a provision of law, which may only become unconstitutional and thus invalid by a legal authority's verdict. The Polish judicial review can be characterised as more declaratory-the CT issues verdicts on the objective state of a law's unconstitutionality - although its verdicts are, in most cases, only effective pro futuro. ${ }^{11}$

\section{Logical Analysis}

In the next part of the paper, I will argue and justify why the thesis claiming that the verdict paradox is a variation of the Liar paradox is incorrect. Although my argumentation is based on logic, one might nonetheless object to any kind of logical grounding of the verdict paradox and the CT's decision to pass over the challenged provisions - either in the version advocated by the scholars who perceive verdict paradox as a variant of the Liar paradox, or in mine. This objection relies on the conviction that the verdict paradox is merely a temporal rather than logical issue, and can be formulated in the following way. Assuming

\footnotetext{
${ }^{10}$ For instance, a verdict given by a body that is competent to review legislation and claim the unconstitutionality of a rule makes this rule invalid, although some legal systems allow for minor exceptions (see, e.g., infra note 11).

${ }^{11}$ In the case of procedures wherein the final decision had been ordered on the basis of a law that has been determined unconstitutional, it is possible that such procedures may be reopened and a new decision may be ordered on the basis of the constitutional law.
} 
the declaratory version of judicial review, the amendment's provisions are objectively unconstitutional and, therefore, invalid; as they are invalid, the former version of the Statue on the CT was a valid law and should have been applied. I believe this is incorrect; one needs to assume the unconstitutionality of the amendment's provisions in order to justify that the provisions are unconstitutional. One assumes in advance a premise that one wants to achieve in the conclusion, which is a fallacy. Moreover, let us assume that the subject of a judicial review and the basis of a judicial review are the same, yet the unconstitutionality of a law is highly unclear, contrary to the analysed case of the amendment to the Statue on the CT. One cannot simply assert that the law which will be reviewed is unconstitutional before this fact has actually been ascertained. If it is passed over and a judicial review is performed on the basis of a former version of this law or the Constitution itself, and if the verdict is that the law is constitutional, then an invalid law has been applied, and the correctness of such a verdict is highly questionable. A temporal view on the verdict paradox is not appropriate, which is why I propose an analysis of the verdict paradox in logical rather than solely temporal terms.

Prime facie, note that the Liar paradox also involves the second situation wherein falsity entails truth. This is hardly imaginable in the verdict paradox and it should be formulated as follows: 'on the basis of the unconstitutional provisions of the amendment, it is the Constitutional Tribunal's decision that the provisions of the amendment are constitutional'. This seems rather strange; how is it possible to review some of the provisions of a statute on the basis of exactly the same unconstitutional provisions of a statute? After all, every statute (and its provisions) is generally considered constitutional and valid until the decision of a competent body reviews it in accordance with the doctrine of constitutionality assumption. Generally, the doctrine of constitutionality assumption is mainly connected with the view that if a statute can be interpreted in way $\mathrm{A}, \mathrm{B}$, or $\mathrm{C}$, wherein the interpretation $\mathrm{A}$ is unconstitutional, then the statute should be interpreted only in ways $\mathrm{B}$ or $\mathrm{C}$; this face of the doctrine mainly involves legal interpretation. The other face of this doctrine, which is more important for the analysis herein, involves the assumption that a law is generally constitutional until the decision given by a competent body states otherwise. ${ }^{12}$ To the best of my knowledge, none constitution explicitly provides such a doctrine. Rather, it is derived from other provisions - e.g. in the Polish legal system the CT derived it from the provision of art. 2 of the Constitution, which states that "the Republic of Poland shall be a democratic state ruled by law and implementing the principles of social justice" (Constitution of the Republic of Poland, art. 2). However, CT judges are bound only by the Constitution and, thus, the doctrine of constitutionality assumption does not involve the judges in the meaning that they should treat a law as constitutional until it is reviewed

\footnotetext{
${ }^{12}$ The 2015 assault on the CT and other assaults committed by the Law and Justice against the judiciary-especially against the amendment to the Statue on the Supreme Court-provided grounds for a deeper doctrinal analysis of this doctrine (Pietrzykowski, 2016; Grabowski, 2018). Interestingly, Grabowski (2018) claims that, in the Polish legal system, the assumption of constitutionality is not necessarily equivalent to the assumption of validity. With regard to the question about whether or not common courts are bound by this doctrine under the Polish legal system, see supra note 2.
} 
by a competent body, since they constitute this competent body themselves. In addition, the declaratory judicial review corresponds with this doctrine; a law is considered constitutional and thus valid until the CT's declaratory decision is made. Nonetheless, if it is unconstitutional, it is simply considered unconstitutional from the very beginning despite the previous assumption of its being constitutional.

Moreover, unconstitutional provisions of law are invalid provisions of law, ${ }^{13}$ which, actually, makes them not being law at all - just as a false friend is no friend at all. In order for legal reasoning to be legal reasoning, only the legal premises (and not non-legal premises) must be applied. ${ }^{14}$ Consequently, one cannot use unconstitutional legal norms (which are not simply legal norms) in the normative aspect of legal reasoning. For that reason, the second situation wherein unconstitutionality would entail constitutionality is impossible for the verdict paradox; thus, the verdict paradox cannot be regarded as a variation of the Liar paradox in the legal domain.

Even for a proponent of the constitutive judicial review, the second version would create a significant problem. Under the constitutive judicial review, provisions of the amendment would have been considered constitutional until the verdict was given by the CT. If the CT passed the verdict on the basis of the amendment's provisions - which are constitutional and valid - and stated that the amendment's provisions are unconstitutional, then they would become unconstitutional only after the verdict had been issued. ${ }^{15}$ One may argue that they would become unconstitutional at the moment of the verdict's issuance; however, let us assume they would become unconstitutional immediately after the verdict's final sentence has been read. Notwithstanding, legal rules would be reviewed on their own basis and - although there is no place to perceive the Liar paradox as one holds the constitutive view on judicial review - a problematic self-reference occurs. This would be like claiming: 'on the basis of the fact that snow is white, I conclude that snow is white'. Thus, even for a proponent of the constitutive judicial review-which I proved false with regard to the Polish legal system - the CT's decision would require another legal basis in addition to the challenged provisions of the amendment. This is also an argument against treating verdict paradox as only temporal issue under the constitutive judicial review. Since I had already provided argument against treating verdict paradox as only a temporal

\footnotetext{
${ }^{13}$ With several examples concerning the Polish law specifically. In certain situations, the Polish CT is able to decide upon another ending date for the binding of a legal act (art. 190 [3], Constitution).

${ }^{14}$ Obviously, I do not exclude moral norms if a legal theory-e.g. Dworkins' theory or inclusive legal positivism-includes them in the legal system.

${ }^{15}$ Gizbert-Studnicki analyses another, but similar, type of argumentation regarding the correctness of the verdict of $9^{\text {th }}$ March, 2016, which is the claim that - in accordance with the Polish Constitution-CT verdicts are final and binding, and due to their ex nunc (pro futuro) effect, "in the moment of the issuance of the Award, the challenged provisions could not yet be deemed unconstitutional, and therefore, no paradox is triggered" (2017). However, the author rejects such a line of argumentation with the claim that the CT must not pass a verdict with an underlying logical paradox. As he states, "First, the fact that awards of the Tribunal are final and binding, even if they are wrong, does not support the conclusion that the Tribunal is free to issue any award notwithstanding logic and generally accepted rules of judicial reasoning. A lack of logic triggers a lack of authority" (2017).
} 
issue under the declaratory review, verdict paradox cannot be solved by temporal means in any situation. As Tomasz Gizbert-Studnicki (2017) claims, "A lack of logic triggers a lack of authority". Under any theoretical view on judicial review, the CT must separate the identity of the subject of review and the basis of review.

Nonetheless, the proponents of the application of the Liar paradox might get involved in a more abstract reasoning rather than a merely concrete process of passing a verdict, as accomplished by either the Polish CT or the general constitutional court. I believe that not only should a concrete manner of judicial review be analysed, but a more abstract reasoning is worth investigating as well, which might illuminate and uncover subtle aspects of the nature of legal norms and legal reasoning within the analysed area. Therefore, the following analysis accommodates certain cases that are impossible in situations faced by constitutional courts of our, i.e. this world's, legal systems. On the abstract level, four variants of reasoning should be distinguished, namely:

(1) On the basis of the constitutional provisions of the amendment, the Constitutional Tribunal decides that the provisions of the amendment are constitutional.

(2) On the basis of the constitutional provisions of the amendment, the Constitutional Tribunal decides that the provisions of the amendment are unconstitutional.

(3) On the basis of the unconstitutional provisions of the amendment, the Constitutional Tribunal decides that provisions of the amendment are constitutional.

(4) On the basis of the unconstitutional provisions of the amendment, the Constitutional Tribunal decides that the provisions of the amendment are unconstitutional.

I believe that my analysis might be easily and more generally extended to the cases whereby 'provisions of the amendment' would be replaced with 'the statute', and 'the Constitutional Tribunal' with 'the constitutional court'. I shall adhere to my formulation, since the primary aim of this paper is to examine the issue on the basis of the Polish constitutional crisis.

Somewhat more formally, the above-mentioned variants can be formulated as follows:

(1) $\mathrm{A}=1 \rightarrow \mathrm{A}=1$.

(2) $\mathrm{A}=1 \rightarrow \mathrm{A}=0$.

(3) $\mathrm{A}=0 \rightarrow \mathrm{A}=1$.

(4) $\mathrm{A}=0 \rightarrow \mathrm{A}=0$.

where ' $A$ ' represents the provisions of the amendment, ' 1 ' represents constitutionality, and ' 0 ' represents unconstitutionality. ${ }^{16}$

\footnotetext{
${ }^{16} \mathrm{~J}$. Woleński takes advantage of a greater number of symbols wherein a statute under review is ' $U$ ', the applied procedure is ' $\mathrm{P}$ ', and the reviewing body is ' $\mathrm{O}$ ' $(2018, \mathrm{p}$. 78). I do not believe that the introduction of a larger number of symbols is necessary for the purposes herein.
} 
Firstly, note that only the situations (2) and (3) can be prima facie qualified as a sort of the Liar paradox, because they involve a change from the value of constitutionality towards the value of unconstitutionality, and vice versa. ${ }^{17}$

Moreover, one can represent the above-mentioned reasonings by drawing implications from propositional logic:

(1) If the provisions of the amendment are constitutional, the provisions of the amendment are constitutional.

(2) If the provisions of the amendment are constitutional, the provisions of the amendment are unconstitutional.

(3) If the provisions of the amendment are unconstitutional, the provisions of the amendment are constitutional.

(4) If the provisions of the amendment are unconstitutional, the provisions of the amendment are unconstitutional.

These implications can be formulated in the following ways:

(1) $\mathrm{A} \rightarrow \mathrm{A}$

(2) $\mathrm{A} \rightarrow \sim \mathrm{A}$

(3) $\sim \mathrm{A} \rightarrow \mathrm{A}$

(4) $\sim \mathrm{A} \rightarrow \sim \mathrm{A}$

where ' $A$ ' represents the sentence 'the provisions of the amendment are constitutional', while ' $\sim \mathrm{A}$ ' represents the sentence 'the provisions of the amendment are unconstitutional'.

In order to properly apply propositional calculus in the analysed matter, it must be assumed that each implication and each propositional variable (A or $\sim \mathrm{A}$ ) holds true value. Thus, logical contradiction emerges only in variants (2) and (3). For (2), if the implication is true and ' $A$ ' (the antecedent) is true, then ' $\sim A$ ' (the consequence) must also be true. However, if ' $\sim A$ ' is true, then ' $A$ ' is false. ' $A$ ' is true in antecedent, whereas ' $A$ ' - in negation of the consequence - is false. The logical contradiction is that the same variable holds different true/false values. Similarly, for (3), if the implication is true and ' $\sim A$ ' (the antecedent) is true, then ' $A$ ' (the consequence) must also be true. However, if ' $\sim A$ ' is true, then ' $A$ ' is false. And, if ' $A$ ' is false in antecedent and ' $\mathrm{A}$ ' is true in consequence, then another logical contradiction occurs. For these reasons, implications from variants (2) and (3) involve a logical contradiction and, therefore, no proper reasoning can be based on such a logical form.

Variant (2) is the proper formalisation of the concrete problem of the verdict paradox that was faced by the Polish CT. This variant represents a situation in which formally constitutional provisions of the amendment are the basis for the verdict that deems these provisions unconstitutional. This would be the CT's decision unless the body applied the concept of passing over the amendment's provisions during the process of examining their

${ }^{17}$ Cf. Gizbert Studnicki (2017), who was the first author to take notice of this. 
constitutionality. Indeed, this constitutes both a legal and logical problem that might actually be perceived as a logical paradox. Variant (3) involves a logical contradiction taken as an implication, which leads to incorrectness if that contradiction is considered as a reasoning. However, such a reasoning is possible only on an abstract, logical level rather than a real level of legal reasoning, because it is impossible to reason in the legal domain by means of taking advantage of unconstitutional (and, thus, invalid) legal premises.

Furthermore, do cases (1) and (4), wherein a logical paradox does not occur, deny that the thesis' argument regarding the CT's passing over the amendment during the review process is correct? Indeed, these cases do not involve a reasoning from constitutionality to unconstitutionality or vice versa, which was a major prima facie argument for the proponents of the Liar paradox. Case (1) might specifically put forward an argument for such a denial, as some would claim that there is nothing paradoxical on either the logical or legal levels that would make it possible to conclude the constitutionality of the amendment on the basis of this amendment, which is constitutional.

I firmly believe that cases (1) and (4) do not deny the correctness of the CT's decision, but, rather, they affirm it. Cases (1) and (4) involve a situation wherein - on the basis of a known constitutional/unconstitutional value - it is implied that this value is just as it is in premise. As Gizbert-Studnicki (2017) writes:

Second, the liar paradox arises on both sides, irrespective of whether we assume that the sentence 'I am lying' is true or false. This is not the case for the paradox involving the Award. The paradox could have been avoided if the Tribunal had decided that the procedural rules of the Amending Agreement were not unconstitutional, but that would mean that logically (for the purpose of making the Award free of logical paradox), the Tribunal would have to confirm the constitutionality of the rules in question. This also appears to be paradoxical and is, in any event, at odds with the very nature of judicial review. (Gizbert-Studnicki, 2017)

Gizbert-Studnicki argues against the view holding that the verdict paradox is a type of the Liar paradox due to the possibility that the paradox may be avoided by asserting the amendment's constitutionality. In such a case, both-sided changes of values do not occur. However, he claims that it is not the role of the CT to search for the manner in which a logical paradox should be avoided, but, instead, to simply review the law. On the other hand, he also states, "I believe that it is paradoxical to say either 'on the basis of the rule $\mathrm{R}$, I decide that the rule $\mathrm{R}$ is valid' or 'on the basis of Rule R, I decide that rule R is not valid"” (Gizbert-Studnicki, 2017).

Gizbert-Studnicki also regards a scenario described in the situation (1) as a paradox, although upon interpreting his line of argumentation as a whole one could consider this as a type of paradox that is different from the Liar paradox. As I agree with this stance, I shall present thorough argumentation for that claim. First of all, there is nothing logically paradoxical in the implication of cases (1) and (4), as these are situations wherein no logical contradiction occurs. However, I believe that such a reasoning is trivial, albeit logically correct. It involves stating a property (in this case, constitutional/unconstitutional) on the basis of this property itself. It is analogical to the following reasonings: 'on the basis of 
the fact that grass is green, I state that grass is green', or 'given that Poland is in Africa, it is true that Poland is in Africa'. From a logical point of view, there is nothing paradoxical here and such reasonings - however trivial—are formally correct. Yet, such a reasoning is not helpful when trying to acquire new knowledge regarding the colour of grass or the place where Poland is located. They can be formulated through propositional logic in the following way:

(5) $\mathrm{p} \rightarrow \mathrm{p}$

(6) $\sim$ q $\rightarrow \sim q$

These are obvious tautologies of propositional calculus, which makes such sentences trivially true and meaningless; they are correct although trivial, which is also true for cases (1) and (4). Moreover, from the epistemological point of view these reasonings are cognitively pointless, because they do not provide any new information about the constitutionality or unconstitutionality of the amendment, which, after all, is the fundamental purpose of judicial review. Alf Ross described a similar situation on the basis of the problem of the constitutional competence norm in order to amend the constitution; he has argued that sentences (legal norms) that refer to themselves take the form 'This sentence is true' rather than 'This sentence is false', as is the case with the Liar paradox. He has indicated that "although the sentence 'This sentence is true' does not give rise to paradoxes, it is still just as meaningful as the paradox-creating Liar" (Ross, 1969, p. 16). ${ }^{18}$

Note that if one ascribes the value of truth to the sentence 'This sentence is true', then this sentence is true, whereas if one ascribe the value of falsity to the same sentence, then the sentence is false. What is obtained is the same value as that which had previously been ascribed, thus distinguishing a self-reference paradox from the Liar paradox, in which not only self-reference occurs, but — after ascribing the value of truth — falsity is also achieved, and-after ascribing falsity - truth is obtained. Such a situation appears in variants (1) and (4), in which the same ascribed value is achieved - a pointless issue.

\section{Conclusions}

Although the problem underlying the review of the amendment on the basis of the amendment itself involves neither a logical contradiction nor a logical paradox within each of the variants, it is indeed a type of paradox involving a peculiar contradiction that can be described as a 'constitutional contradiction' (Matczak, 2016). ${ }^{19}$ As Marcin Matczak states:

The potential verdict determining its [the amendment's] unconstitutionality cannot be based on it. If it were so, a constitutional contradiction would be reached: a verdict determining unconstitutionality of a statute would be passed on the basis of unconstitutional provisions and, thus, it would be defective. In order not to lead to such a contradiction, the CT cannot

\footnotetext{
${ }^{18}$ With regard to the question of self-reference, see also Hart (1978) as well as Bartlett and Suber (1987).

${ }^{19}$ Cf. Woleński (2018), who also claims that the verdict paradox does not involve a logical paradox, although it does involve some other sort of paradox.
} 
adjudicate upon the constitutionality of the amendment on the basis of its provisions (2016, 4.3.1, translation mine).

However, the intuition of the proponents of applying the Liar paradox was, at least to some extent, correct. As it has been presented, a logical paradox occurs only in those situations in which — on the basis of the constitutional amendment - the CT would determine its unconstitutionality and vice versa, which I formulated as variants (2) and (3). Variant (2) would have been 'our world' situation if the CT had not passed over the amendment during the judicial review process. Therefore, we can go beyond Matczak's considerations and claim that, in variant (2), a truly logical contradiction emerges rather than merely a constitutional contradiction. A logical contradiction also occurs in variant (3), although such a reasoning is only abstractly conceivable, since invalid premises cannot represent premises in the legal reasoning. The reasonings from variants (1) and (4) are logically correct, although the trivial possibility of employing such a reasoning must be excluded. The triviality found on the logical (abstract) level in variants (1) and (4) remains correct on the concrete level of a legal system's analysis. What is epistemologically trivial on the logical level is also epistemologically trivial on the practical, legal level. The concrete level of analysis makes it possible for variant (4) to be excluded on the same basis as variant (3), which makes taking advantage of invalid legal rules during the process of judicial review - and, broadly, in any legal reasoning_impossible. Variant (2) has been excluded on the logical level of analysis and its evaluation remains the same on a concrete, practical ('our world'), legal level.

To summarise, on the abstract, logical level, the reasonings from variants (2) and (3) involve a logical contradiction, whilst the reasonings from variants (1) and (4) involve triviality. On the real level of the legal system and legal reasoning, the reasonings from variants (3) and (4) are impossible to ascertain, since they rely on unconstitutional and, therefore, invalid legal rules, which are actually not legal rules at all.

Therefore, because each variant has been excluded even on the abstract level-two of them due to a logical contradiction and the other two due to triviality - the problem of the verdict paradox was a real logical and, consequently, legal adjudication paradox. Furthermore, the CT's decision to pass over the amendment's provisions that were to be reviewed during the judicial review process was correct; it was a brilliant way to remove the paradox that had been encountered by the $\mathrm{CT}$ due to the parliamentary assault on its constitutional position. Nevertheless, the verdict paradox was not a type of the Liar paradox. It is important to underline that passing over the challenged provisions was the only way to issue a logically correct verdict rather than exclusively an unconstitutional verdict of the amendment. Some participants in the public debate claim that the CT's decision to pass over was performed instrumentally in order to provide a logically correct verdict regarding the unconstitutionality of the amendment. For the proponents of such a view, the CT firstly intended to review the amendment and declare its unconstitutionality, and with such a decision 'in mind', the CT was looking for any way this could have been accomplished. My analysis falsifies such a view; if the CT had wanted to declare the constitutionality of 
the amendment, it would still have needed to pass over its challenged regulations. Otherwise, the reasoning would adopt variant (1), which is trivial, and a proper verdict could not be based on such a logical form.

From the perspective of political freedom and its constitutional guarantees, the verdict paradox masterfully exemplifies the fact that a parliamentary majority wishing to remove the constitutional court in a democratic state governed by the rule of law faces numerous serious legal and logical obstacles. Moreover, democratic institutions, such as the CT in the analysed issue, possess many tools with which to defend their position - not only that of a political or even legal character, but also that of a logical character, such as the necessary passing over the challenged provisions. There are other postulated ways to defend the CT's decision to pass over the challenged regulations - e.g. the view that it was justified due to institutional self-defence (Matczak, 2017; Małecki \& Pach, 2018). However, institutional self-defence is a new idea (Barber, 2013), one involving many essentially contested concepts. It is an idea derived from political philosophy and, as I do not reject the other justifications of the CT's decision, I believe that grounding the verdict paradox and its resolution in logic is more plausible and convincing. Logic is universal, while, regretfully, conceptions from within political philosophy are not. What I regard as particularly significant is that some of these legal obstacles touch on a very deep logical level of interpretation and reasoning in general. This level demonstrates that logic and reason can defend democratic institutions that constitute a guarantee of the rule of law and, in such a mediated manner, political freedom itself. I find it really valuable as it indicates that political freedom is not a contingent child of some particularly modern philosophical investigations; it is plausible to claim that the rule of law and political freedom are truly reasonable and logical public-life attitudes.

\section{References}

Barber, N. (2013). Self-defence for institutions. Cambridge Law Journal, 72(3), 558-577.

Bartlett, S. J., \& Suber P. (1987). (Eds). Self-Reference: Reflections on Reflectivity, Dodrecht, the Netherlands: Martinus Nijhoff Publishers.

Czarnota, A. (2017, June 3). The Constitutional Tribunal. VerfBlog. Retrieved from https://verfassungsblog.de/the-constitutional-tribunal/

Dziadzio, A. (2018). Quis custodiet ipsos custodes? Die Auseinandersetzung um den Verfassungsgerichtshof in Polen (2015-2016). Osteuropa Recht, 64(1), 21-38.

Fine, K. (2002). Varieties of Necessity. In T. S. Gendler \& J. Hawthorne (Eds.), Conceivability and Possibility (pp. 253-281). Oxford, UK: Clarendon Press.

Gizbert-Studnicki, T. (2017, June 3). A state of constitutional necessity versus standard legal reasoning. VerfBlog. Retrieved from https://verfassungsblog.de/a-state-of-constitutional-necessity-versus-standard-legal-reasoning/ 
Grabowski, A. (2018, July 10). Domniemanie konstytucyjności to nie domniemanie obowiązywania. Konstytucyjny.pl. Retrieved from http://konstytucyjny.pl/domniemanie-konstytucyjnosci-tonie-domniemanie-obowiazywania-andrzej-grabowski/

Hart, H. L. A. (1983). Self-Referring Laws. In Essays in Jurisprudence and Philosohy (pp. 170178). Oxford, UK: Clarendon Press.

Małecki, M., \& Pach, M. (2018). Stan wyższej konieczności konstytucyjnej. Państwo i Prawo, 7, 38-57.

Matczak, M. (2016). Opinia dla Fundacji Batorego z 19.01.2016 r. Retrieved from http://trybunal.gov.pl/uploads/media/K_47_15_FB_2016_02_25_ADO_02.pdf

Matczak, M. (2017, June 3). Self defence of public institutions in the Polish constitutional crisis. VerfBlog. Retrieved from https://verfassungsblog.de/self-defence-of-public-institutions-inthe-polish-constitutional-crisis/

Matczak, M. (2018). Polish Constitutional Crisis: Facts and Interpretations. Oxford, UK: The Foundation for Law, Justice and Society. Retrieved from http://www.fljs.org/sites/www.fljs.org/files/publications/Poland\%27s\%20Constitutional\%20Crisis\%20-\%20Facts\%20and\%20interpretations_0.pdf

Młynarska-Sobaczewska, A. (2017). Polish Constitutional Tribunal Crisis: Political Dispute or Falling Kelsenian Dogma of Constitutional Review. European Public Law, 23(3), 489-506.

Morawski, L. (2017, June 3). A critical response. VerfBlog, 2017/6/03. Retrieved from https://verfassungsblog.de/a-critical-response/

Pach, M., \& Dyrda, A. (2016, March 23). Paradoks trybunalski i koń trojański, Rzeczpospolita.

Pach, M., \& Dyrda, A. (2016, April 23). Paradoks trybunalski: Czy dało się go uniknąć? Rzeczpospolita.

Pietrzykowski, T. (2016). Czym jest domniemanie konstytucyjności? Radca.pl (3), 16-23.

Radziewicz P. (2017). Refusal of the polish Constitutional Tribunal to apply the act stipulating the constitutional review procedure. Review Of Comparative Law, 28, 23-40.

Ross, A. (1969). On Self-Reference and a Puzzle in Constitutional Law. Mind, 78(309), 1-24.

Rumberg, A. (2016). Transitions Toward a Semantics for Real Possibility. Utrecht, the Netherlands: Utrecht University.

Stębelski, M. (2017). Parliament versus Constitutional Court: Selected Issues Pertaining to the Constitutional Dispute in Poland. In M. Szabó, P. L. Láncos, \& R. Varga (Eds.), Hungarian Yearbook of International and European Law 2016 (pp. 407-430). The Hague, The Netherlands: Eleven International Publishing.

Suber, P (1990). The Paradox of Self-Amendment: A Study of Law, Logic, Omnipotence, and Change. Bern, Switzerland: Peter Lang International Academic Publishers.

Woleński, J. (2012). Z zagadnień analitycznej filozofii prawa, Kraków, Poland: Aureus.

Woleński, J. (2018). Paradoks obowiązywania prawa na przykładzie sporu o Trybunał Konstytucyjny. In P. Jabłoński, J. Kaczor, \& M. Pichlak (Eds.), Prawo i Polityka w Sferze Publicznej: Perspektywa Zewnętrzna (pp. 77-81). Wrocław, Poland: E-Wydawnictwo. Prawnicza i Ekonomiczna Biblioteka Cyfrowa. 